\title{
С.М. Стадніченко
}

\section{ОСОБЛИВОСТІ КАТАГЕНЕЗУ В ОСАДОВИХ БАСЕЙНАХ, ЩО МІСТЯТЬ ГАЛОГЕННІ ФОРМАЦІЇ}

\author{
S.M. Stadnichenko
}

\section{THE CATAGENESIS PECULIARITIES OF THE SEDIMENTARY BASINS WHICH CONTAIN SALT FORMATIONS}

Проаналізовано розвиток поглядів на катагенетичні перетворення порід осадових басейнів, що містять галогенні формації, та виокремлення галокатагенезу як окремого типу катагенезу. Розглянуто вплив гідрогеологічних чинників та літолого-мінерального складу порід на перебіг та результати галокатагенезу. Описано мінеральні продукти галокатагенезу (новоутворення доломіту, ангідриту та галіту), виявлені у відкладах нижньої пермі південно-східної частини Дніпровсько-Донецької западини. Показано теоретичне (як окремого різновиду катагенетичних перетворень) і практичне значення процесів галокатагенезу (зміна колекторських властивостей порід, формування високомінералізованих металоносних розсолів) та ін.

Ключові слова: галокатагенез, галогенна формація, розсіл, мінеральні новоутворення.

Проанализировано развитие взглядов на катагенетические преобразования пород осадочных бассейнов, содержащих галогенные формации, и выделение галокатагенеза как отдельного типа катагенеза. Рассмотрено влияние гидрогеологических факторов и литолого-минерального состава пород на ход и результаты галокатагенеза. Описаны минеральные продукты галокатагенеза (новообразования доломита, ангидрита и галита), обнаруженные в отложениях нижней перми юго-восточной части Днепровско-Донецкой впадины. Показано теоретическое (как отдельной разновидности катагенетических преобразований) и практическое значение процессов галокатагенеза (изменение коллекторских свойств пород, формирования високоминерализованных металлоносных рассолов) и др.

Ключевые слова: галокатагенез, галогенная формация, рассол, минеральные новообразования.

Progress of the views about rock catagenesis conversions of the sedimentary basins which contain salt formations and galocatagenesis defines as a different type of the catagenesis has been analyzed. The impact of the hydrogeological factors and lithology-mineralogical rocks compound at the galocatagenesis process and results have been examined. The galocatagenesis mineral products (neogenic dolomite, anhydrite and halite) located in the lower Permian sediments of the south-western part of the Dnipro-Donets basin have been described. The theoretical (as a different type of the catagenetic conversions) and practical importance of the galocatagenesis processes has been showed.

Keywords: galocatagenesis, salt formation, brine, neogenic minerals.

ВСТУП

Наявність потужних соленосних товщ у розрізі осадових басейнів призводить до формування підземних вод і розсолів, принципово відмінних за хімічним складом і мінералізацією. Тому катагенез* порід осадових басейнів, що містять галогенні товщі, може бути зрозумілий тільки з врахуванням їх впливу або, за термінологією В.І. Вернадського, динамічної рівноваги розсоли-евапорити.

Вже понад століття проводяться дослідження окремих аспектів взаємодії в системі водапорода вченими: літологами - А.Є. Ферсманом, М.М. Страховим, Л.В. Пустоваловим, М.В. Логвиненко, А.В. Копеліовичем, В.М. Холодовим, О.В. Япаскуртом, А.О. Махначем, гідро- геологами - А.Є. Бабинцем, Є.В. Посоховим, Б.І. Куделіним С.Л. Шварцевим В.В. Колодієм, Є.В. Піннекером, Д.П. Шваєм, М.Г. Валяшком, К.М. Варавою, Г.В. Богомоловим, геологаминафтовиками - М.Б. Вассоевичем, О.Ю. Лукіним, А.Е. Конторовичем, С.Г. Неручевим та ін. Проте фахівці неодноразово вказували на необхідність застосування комплексного підходу до вирішення цієї проблеми.

Враховуючи специфічний характер процесів взаємодії в системі вода-порода басейнів із потужними товщами галогенних порід, широкі масштаби розвитку, велике практичне (із галогенними формаціями генетично і парагенетично пов'язані родовища вуглеводнів, безпосередньо сировина кам'яної, калійної

\footnotetext{
*Катагенез (термін, що походить від грец. “ката» - вниз) трактується як стадія речовинно-структурних перетворень, що відбуваються вже у власне осадовій породі при підвищеному тиску 10-200 МПа і температурі приблизно 25-200 C $\left( \pm 25^{\circ} \mathrm{C}\right)$ за наявності і активної участі підземних вод та (або) порових розчинів (Логвиненко, Орлова, 1987; Тимофєєв, 1994; Япаскурт, 1999, 2004, 2005, 2008).
}

(C) С.М. Стадніченко, 2010 
солей і бішофіту, самородної сірки та ін.) і теоретичне значення, їх було виділено в особливу групу постдіагенетичних перетворень. Згідно із даними А.О. Махнача (1981, 1989, 2000), катагенетичні зміни, що відбуваються під впливом надходження розсолів різного генезису в міжта підсольову систему вода-порода, об'єднано понятям «галокатагенез" [9]. В.М. Холодов [17] виділив даний тип катагенезу як "розсольногравітаційний" для осадових басейнів інфільтраційного типу. О.В. Япаскурт [11] виділяє гравітаційно-розсольний підтип катагенезу в рамках інфільтраційного типу катагенезу як процес перетворення порід під впливом інфільтрації розсолів вилуговування.

Галокатагенез $є$ багатофакторним процесом, який відбувається в багатокомпонентній системі вода-порода-газ. Фактори: геодинамічна обстановка, що зумовлює p,t-умови; літологомінеральний, хімічний склад порід; гідрогеологічні умови; геологічний час. Геодинамічна обстановка $€$ одним із найважливіших факторів, що визначає гідродинамічний режим регіону: напрямок, швидкість і характер руху підземних вод і безпосередньо впливає на перебіг та результати процесів взаємодії в системі водапорода.

Метою даної роботи є постановка проблеми та обгрунтування актуальності досліджень процесів галокатагенезу в осадових басейнах, що містять галогенні формації.

Вирішувались такі задачі: 1) аналіз літологомінералогічних, гідрогеохімічних та гідродинамічних факторів галокатагенезу; 2) характеристика мінеральних продуктів галокатагенезу; 3) практичні аспекти - аналіз впливу галокатагенетичних перетворень на колекторські властивості нафтогазоносних порід, формування родовищ промислових йод-бромних, поліметальних вод та ін.

Дослідження цього типу катагенезує актуальним для України, де, як відомо, є чотири осадових басейни 3 потужними галогенними формаціями: Передкарпатський, Закарпатський, Переддобрудзький та Дніпровсько-Донецький.

Вивчення процесів взаємодії в системі вода-порода, що зумовлена надходженням у між- та підсольові комплекси розсолів, поділяється на дослідження механізмів аутигенного мінералоутворення та зміни (метаморфізації*) хімічного складу розсолів.
ЛІТОЛОГО-МІНЕРАЛОГІЧНІ ТА ГІДРОГЕОЛОГІЧНІ ЧИННИКИ ГАЛОКАТАГЕНЕЗУ

Вивченню питання генезису, динаміки і формування хімічного складу підземних вод басейнів 3 потужними товщами галогенних формацій присвячено роботи А.Є. Бабинця, Є.В. Посохова, Б.І. Куделіна С.Л. Шварцева, В.В. Колодія, Є.В. Піннекера, Д.П. Швая, М.Г. Валяшка, К.М. Варави, Г.В. Богомолова, В.І. Лялька, К.І. Макова, Л.К. Гуцала, Ю.С. Застежка, В.А. Кривошеї, Е.Е. Лондона, А.Ф. Романюка, В.А. Терещенка, О.А. Махнача та ін.

Як відомо, розробляється три концепції генезису підземних вод - седиментаційна, інфільтраційна та ювенільна [1]. Проте у зв'язку із наявністю в розрізі басейну осадконакопичення галогенних формацій розроблено гіпотези формування розсолів, що поділяються на такі групи: магматогенна (ювенільних вод); седиментогенна (нерозбавленої ропи басейнів седиментації); седиментогенно-інфільтрогенна (метаморфізованих вод різного генезису) та інфільтрогенна [3, 6, 44].

Басейни 3 галогенними формаціями (сульфатними, галітовими, калійними) містять підземні води широкого діапазону мінералізації - розсоли натрієвого, кальцієвого і рідше магнієвого складу (під терміном "розсоли” в даній роботі розуміються води із мінералізацією понад 35 г/л, за А.І. Дзенс-Литовським, І.К. Зайцевим, М.Г. Валяшком, Є.В. Піннекером) [3].

Ювенільна гіпотеза не пояснює деяких геохімічних особливостей та закономірностей поширення розсолів, тому за генезисом виділяють:

- Води вилуговування (формуються в результаті вилуговування (розчинення) галогенних мінералів інфільтрогенними водами) - при загальній мінералізації менше 320 г/л розсоли мають зазвичай хлоридний натрієвий склад (характеризуються низькими концентраціями кальцію, магнію, стронцію, калію, літію, брому та йоду, концентрація сульфату-іону звичайно досить висока); коли вилуговуються калійні солі, різко зростає концентрація калію і брому.

- Седиментогенні води (води басейнів седиментації) і води змішаного генетичного типу (в яких седиментогенні води певною мірою заміщені давніми інфільтрогенними водами і метаморфізовані в результаті їх взаємодії з вміщуючими породами) - при мінералізації понад 320 г/л мають хлоридний натрій-кальцієвий,

*Метаморфізація розсолів - сукупність геохімічних процесів, що відбуваються з розсолами після їх захоронення у вміщуючих породах (Крайнов, Швець 1992). 
кальцієвий або магнієвий склад. Через високий ступінь мінералізації, що перевищує розчинність $\mathrm{NaCl}$ у воді, ці розсоли називають концентрованими [12]. В підвищених кількостях вони містять калій, бром, стронцій, сірководень, а також літій, барій, бор та інші елементи, мало сульфатів [1, 3, 6, 12].

Концентровані хлоридно-кальцієві розсоли широко розповсюджені в палеозойських відкладах Прип'ятсько-Дніпровсько-Донецького авлакогену, кембрійських породах Сибірської платформи, відкладах девону Північноамериканської платформи та ін. [1, 3, 10, 12, 34].

Встановлено геохімічні критерії, що дозволяють відокремити розсоли седиментогенні від розсолів вилуговування, а також перехідні між ними розсоли змішаного генетичного типу. В якості основного критерію генетичного розподілу розсолів зазвичай використовується залежність між $\mathrm{rNa} / \mathrm{rCl}$ та $\mathrm{Cl} / \mathrm{Br}$ коефіцієнтами, що відображає природні процеси концентрації морської води в сучасних лагунах і процеси вилуговування солей. Наприклад, високомінералізовані Са-Cl розсоли поширені в підсольовій товщі пермського басейну Західного Техасу і Оклахоми, $(\mathrm{rNa} / \mathrm{rCl}<0,8 ; \mathrm{M}>300 г / л)$, тоді як $\mathrm{Na}-\mathrm{Cl}$ розсоли вилуговування $(\mathrm{rNa} / \mathrm{rCl}>0,9$; $\mathrm{M}<290 г / л)$ виявлені в надсольовій зоні та глибокозалягаючому водоносному горизонті товщі Вольфкампіан [23, 43].

Розсоли цих типів суттєво відрізняються не тільки за хімічним складом, а й за місцем поширення в розрізі басейну. В осадових басейнах, що містять галогенні формації, виділяють надсольову (навколосольову), між- і підсольову зони катагенетичних перетворень. У над- і навколосольовій зонах осадових басейнів залягають розсоли вилуговування $[2,10,11]$. В під- і міжсольовій зонах поширені седиментогенні розсоли та розсоли змішаного типу [2, 10, 17]. Під регіонально витриманими гіпсо-ангідритовими формаціями звичайно залягають седиментогенні розсоли 3 мінералізацією 140-280 г/л, під галогенними формаціями, представленими кам'яною і калійно-магнезіальними солями, а також між цими формаціями і в середині них розсоли із мінералізацією 280-600 г/л.

Основними механізмами надходження розсолів у під- і міжгалогенні товщі $є$ струменеве гравітаційне просочування важких розсолів вниз, а більш легких вод уверх (по порах, тріщинах, розломах і зонах бокових контактів соляних куполів), а також відтискання міжкрис- тальної ропи, що може видалятися із соляних відкладів, в результаті їх ущільнення (за елізійним механізмом). При відтисканні, на відміну від гравітаційного стікання, можливе не тільки вертикальне низхідне стікання розсолів, а й латеральний рух під галопелітовими прошарками як безпосередньо по соляних пластах, так і по внутрішньосольових карбонатних і піщаних пачках. Ще одним механізмом поповнення ресурсів розсолів, що мігрують в порово-тріщинному просторі порід між- і підсоленосних зон, є міграція ропи рідких і газово-рідких включень в галогенних мінералах [2, 10, 33].

Перерозподіл маси та розчиненої речовини розсолів здійснюється шляхом гравітаційного переміщення та дифузії, відбувається змішування розсолів різних стадій генерації між собою, а також із первинними маточними водами і дегідратаційними водами (катагенетичних перетворень глинистих мінералів та реакції переходу гіпс-ангідрит) [22]. Ці процеси направлені на зміну хімічного складу та мінералізації підземних вод, що призводить до формування високомінералізованих хлоркальцієвих розсолів.

Галогенні формації містять кальцієві карбонати й ангідрит; коли 3 ними контактують розсоли, гранично насичені $\mathrm{NaCl}$ (мінералізація 320 г/л), створюються умови для нагромадження і концентрації $\mathrm{CaCl}_{2}-$ солі 3 найбільш високою розчинністю. Розсіл перетворюється спочатку в хлоридний натрієвий $\rightarrow$ натрієвий $\rightarrow$ кальцієво-натрієвий, а потім у хлоридний кальцієвий. Джерелом кальцію $є$ карбонати, але провідне значення має перехід кальцію з ангідритів (Шварцев, 1975). Перехід кальцію можливий також з теригенних порід, наприклад при альбітизації плагіоклазів [5].

Сульфати виводяться із розчину у формі гіпсу, а магній - у формі доломіту, що призводить до відносної концентрації хлоридів кальцію. На можливість катагенетичного походження доломіту у зв'язку з формуванням хлоркальцієвих вод вказували В.І. Гуревич, А.І. Осипова, Ю.С. Кормілець, А.О. Махнач та інші вчені. Причиною підвищеного вмісту кальцію може бути і катіонний обмін. При наявності в породах інших сульфатних мінералів рідка фаза збагачується стронцієм, барієм та іншими елементами. Обов'язковими умовами концентрації розсолів вважаються тривалість процесу в масштабі геологічного часу, відновна обстановка і термодинамічні умови, властиві зоні досить утрудненого водообміну [14, 28]. 
Інший склад порід необхідний для утворення хлоридних магнієвих розсолів. Ці розсоли звичайно не контактують із кальційвмісними породами, а пов'язані з товщами кам'яної і калійної солей. Висока концентрація хлориду магнію зобов'язана не стільки маточній ропі, скільки процесам вилуговування карналіту дегідратаційними та інфільтрогенними водами $[12,31]$. Звідси стає зрозумілим приуроченість хлоридних магнієвих розсолів до калійних родовищ (Передуралля, Німеччина, басейн Atalante в Середземному морі та ін.) і, як правило, відсутність їх в карбонатних і ангідритових товщах. Аналогічним чином відбувається й збагачення розсолів калієм. Високі його вмісти в розсолах виявляються тільки там, де в геологічному розрізі поширені калійні солі.

Так, на незначній по площі території Mediterranean Ridge (Східно-Середземноморського валу) виявлено три придонні озера розсолів: Urania, Atalante i Discovery [31]. Розсоли даних озер сформувалися внаслідок підводного розчинення месинських евапоритів (що виходять на поверню дна моря чи близько до неї), наявність яких підтверджена сейсмічними даними. Різниця хімічного складу розсолів даних озер пояснюється розчиненням різних шарів розрізу месинських евапоритів. Підводне розчинення месинських евапоритів відбувається в умовах потужних син- та постмесинських тектонічних деформацій та в місцях, де постмесинські відклади мають незначну потужність. Накопичення розчинених солей (розсолів) можливе за умови існування закритої депресії, в іншому випадку придонні потоки розбавляють та переносять розсоли, що перешкоджає їх накопиченню. Поверхня поділу морської води та розсолу досить чітка, проте вона залягає на різних глибинах у басейні Urania (3455 м) та Atalante (3344 м), які розташовані на відстані кількох кілометрів (рис. 1). Покрівля месинських евапоритів знаходиться вище поверхні розсольного озера південно-східної частини басейну Urania і нижче поверхні розсолу басейну Atalante. Два розсольних озера являють собою дві різні гідрогеологічні системи і відрізняються за хімічним складом. Розсоли озера Atalante суттєво насичені калієм, що, ймовірно, пов'язано із хлоридами калію, які є характерними для найвищих шарів евапоритової товщі. Вміст хлору в розсолах басейну Urania становить 120 г/л, тоді як у Середземному морі - 22 г/л. Розсоли ба-

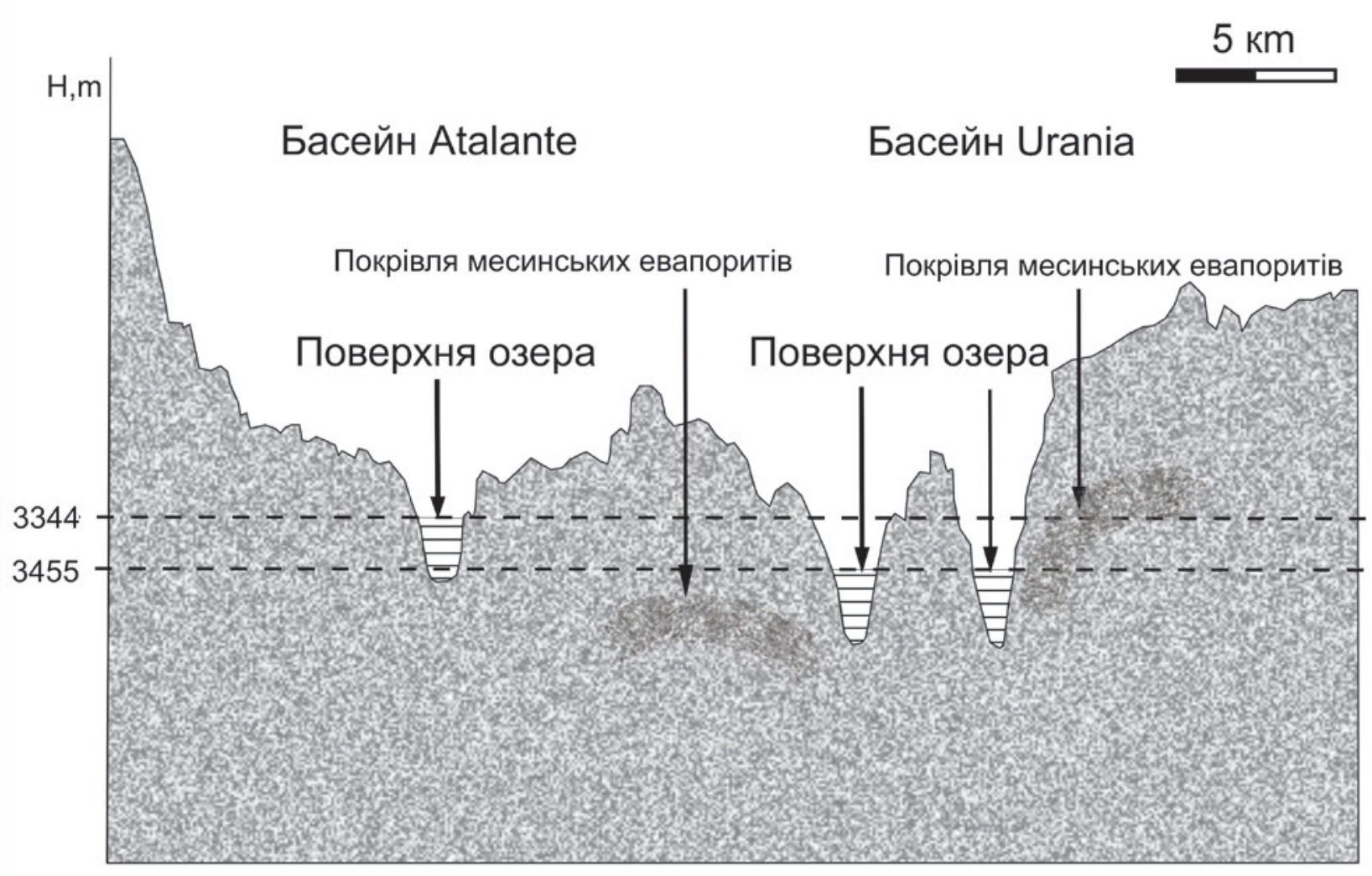

Рис. 1. Сейсмічний профіль дна Середземного моря (території басейнів Urania та Atalante) [31] 
сейну Discovery мають найвищу мінералізацію, будь-коли виявлену в морському середовищі вміст хлору становить 260 г/л. Вони сформувались в результаті розчинення бішофіту.

На надходження багатьох елементів (не тільки Ca, Mg, K, а й Br, B, Li та ін.) з порід вказує подібність мікрокомпонентного складу розсолів і галогенних формацій. Незначні концентрації йоду в розсолах легко пояснюються низьким його вмістом у породах. Переходу елементів із солей у розчин на значних глибинах сприяє молекулярна дифузія; при цьому підвищення температури і тиску може призвести до вибіркового розчинення окремих елементів у кількостях, набагато більших, ніж утримується в ропі [2, 3, $6,7,12,15,17,40,46,48]$. Бром, відповідно до його розподілу в галоїдних солях (галіті, сильвіні і карналіті) здатний переходити в рідку фазу в значних кількостях. Певною мірою бром звичайно успадкований від маточної ропи. Однак у набагато більших кількостях він може надходити з мінералів солей. Варто враховувати, що зі збільшенням температури й тиску розчинність сполук брому сильно зростає [19].

Аналізи хімічного та ізотопного складу підземних вод силур-девонських відкладів басейну Іллінойс (США) вказують на певні геологічні процеси, що призвели до наявного складу розсолів [43]. В результаті метаморфізації хімічного складу седиментогенні розсоли з підвищеним вмістом K і Mg перетворилися на $\mathrm{Na}-\mathrm{Ca}-\mathrm{Cl}$. Спостерігається зменшення вмісту $\mathrm{Na} \mathrm{i} \mathrm{K} \mathrm{внаслідок}$ взаємодії з глинистими мінералами, насичення Ca і втрата Mg в результаті доломітизації карбонатів, підвищенні концентрації $\mathrm{Sr}$ внаслідок перекристалізації $\mathrm{CaCO}_{3}$ та доломітизації. Ізотопні аналізи стронцію вказують на його надходження в результаті катагенетичних перетворень розсолів та ${ }^{87} \mathrm{Sr}$ - насичених нафтових флюїдів, що, ймовірно, мігрували в силурдевонські карбонати із вапняків New Albany. Співвідношення ізотопів кисню вказують також на надходження в розсоли метеорних вод. Таким чином, розсоли басейну Іллінойс $є$ розсолами змішаного типу, що утворилися внаслідок метаморфізації маточних розсолів, надходження метеорних вод та нафтових флюїдів.

Вплив геодинамічної обстановки на гідродинаміку

Описані процеси формування хімічного складу розсолів та механізми їх надходження в суміжні товщі залежать від геодинамічної обстанов- ки, що визначає $p, t$-умови і гідродинамічний режим регіону.

Відповідно до останніх досліджень J.K. Warren, С.Б. Шехунова та ін. [13, 20, 47] серед басейнів, що містять потужні галогенні товщі, розрізняють: осадові басейни рифтів; пасивних, активних та конвергентних окраїн континентів; пост-орогенного занурення; активізації платформ і накладених синекліз.

В таблиці наведено приклади впливу геодинамічної обстановки і роль галогенних відкладів у формуванні хімічного складу та поширенні розсолів ряду осадових басейнів.

Таким чином, потужні галогенні товщі у розрізі басейну седиментації: суттєво впливають на хімічний склад підземних вод (загальну мінералізацію та концентрації макро- і мікроелементів); можуть відігравати роль непроникного екрану, що спрямовує потік тепла і флюїдів на підсоленосні відклади; є джерелом флюїдів (седиметогенних розсолів, маточної ропи); слугують шляхами надходження глибинних флюїдів (зони бокових контактів солянокупольних структур) у вищезалягаючі товщі; призводять до формування високомінералізованих розсолів і осадження з них аутигенного ангідриту, гіпсу, доломіту, галіту та ін.

Процеси взаємодії в розглянутій системі вода-порода призводять до формування розсолів специфічного хімічного складу і викликають катагенетичні перетворення порід в агресивній (нерівноважній) щодо вміщуючих порід обстановці.

\section{МІНЕРАЛЬНІ ПРОДУКТИ ГАЛОКАТАГЕНЕЗУ}

Процеси, об'єднанні поняттям «галокатагенез" призводять до утворення доломіту, гіпсу, ангідриту, галіту та деяких інших мінералів в між- та підсоленосних зонах. 3 тією або іншою детальністю вони охарактеризовані, наприклад, у відкладах кембрію і протерозою Іркутського амфітеатру, ордовику формації Вінніпег (Канада), силуру формації Саліна (США), девону Прип'ятського прогину, пермі, девону і карбону Дніпровсько-Донецької западини (ДДЗ), карбону і пермі Прикаспійської западини, тріасу на півночі ФРН, келовею-оксфорду на сході Туркменії, палеогену Передкарпатського прогину, неогену Польщі та багатьох інших [11]. На рис. 2 представлено електронномікроскопічні знімки новоутворень доломіту, ангідриту, бариту та галіту, виявлені в породах теригенної червоноколірної формації нижньої пермі південно-східної 
Таблиця. Вплив геодинамічної обстановки і роль галогенних відкладів у формуванні хімічного складу та циркуляції розсолів деяких осадових басейнів

\begin{tabular}{|c|c|c|}
\hline $\begin{array}{l}\text { Тип осадового } \\
\text { басейну }\end{array}$ & $\begin{array}{l}\text { Розташування джере- } \\
\text { ла розсолу, його вік }\end{array}$ & Роль галогенних відкладів \\
\hline \multirow{3}{*}{$\begin{array}{l}\text { Осадові басейни } \\
\text { рифтів (pull-apart, } \\
\text { continrntal rift) }\end{array}$} & $\begin{array}{l}\text { Мертве море, Серед- } \\
\text { ній Схід; міоцен }\end{array}$ & $\begin{array}{l}\text { Галогенні відклади є джерелом високої мінералізації розсолів, що призво- } \\
\text { дить до їх перенасичення і аутигенного мінералоутворення } \\
\text { Розчинення галіту Мертвого моря є джерелом розсолів для водоносних } \\
\text { горизонтів навіть на відстані понад } 100 \text { км від рифту. } \\
\text { Розчинення галогенних відкладів міоценового віку та пов'язана з ним } \\
\text { міграція розсолів активізує зони доломітизації в суміжних карбонатних } \\
\text { водоносних горизонтах крейдового віку }[29,41]\end{array}$ \\
\hline & $\begin{array}{l}\text { Прип'ятський прогин; } \\
\text { девон }\end{array}$ & $\begin{array}{l}\text { Галогенні відклади є джерелом флюїду та вторинного мінералоутворення } \\
\text { В галогенних товщах Прип'ятського прогину широко представлені кам'яна } \\
\text { і калійно-магнезіальні (сильвін, карналіт) солі. Ïх осадження було можливе } \\
\text { із ропи з мінералізацією } 280-450 \text { г/л. } \\
\text { Надходження маточної ропи в під- та міжсоленосні товщі обумовило утво- } \\
\text { рення основних мінеральних продуктів галокатагенезу, включаючи галіт } \\
\text { [10] }\end{array}$ \\
\hline & $\begin{array}{l}\text { Дніпровсько- } \\
\text { Донецька западина; } \\
\text { девон }\end{array}$ & $\begin{array}{l}\text { Галогенні відклади є джерелом високої мінералізації розсолів, а зони бо- } \\
\text { кових контактів соляних куполів слугують шляхами надходження глибинних } \\
\text { флюїдів } \\
\text { Підземні води девонських відкладів розміщуються в зоні утрудненого } \\
\text { водообміну. Ступінь метаморфізації цих вод завжди значно вищий, ніж } \\
\text { у водах, поширених на ділянках соляних штоків, які порушують природне } \\
\text { залягання порід, змінюючи гідрогеологічні умови (Ісачківська, Роменська, } \\
\text { Слов'янська, Калайдинцівська, Олишівська структури). На Зачепилівській } \\
\text { солянокупольній ділянці виявлено йод-бромні води із аномально високим } \\
\text { вмістом йоду (50,8-146,5 мг/л), стронцію (500 мг/л) і бору (260 мг/л), що } \\
\text { сформувалися внаслідок вертикальної міграції глибинних флюїдів по зо- } \\
\text { нах тектонічних порушень із підсольових девонських відкладів }[19,20]\end{array}$ \\
\hline \multirow{4}{*}{$\begin{array}{l}\text { Осадові басейни } \\
\text { пасивних окра- } \\
\text { їн континентів } \\
\text { (раssive margin } \\
\text { burial, passive } \\
\text { margin basins, } \\
\text { marginal sag } \\
\text { basins) }\end{array}$} & $\begin{array}{l}\text { Ліонська затока, } \\
\text { Франція; міоцен }\end{array}$ & $\begin{array}{l}\text { Галогенна товща відіграє роль непроникного екрану, що залишається не- } \\
\text { порушеним завдяки пасивному тектонічному режиму занурення басейну } \\
\text { Стратиформна пізньоміоценова галогенна товща представляє собою } \\
\text { потужний екран, що змінює напрямок циркуляції вод і потоку тепла на під- } \\
\text { сольові відклади [25] }\end{array}$ \\
\hline & $\begin{array}{l}\text { Gulf Cost Мексикан- } \\
\text { ська затока; юра }\end{array}$ & $\begin{array}{l}\text { Галогенні відклади є джерелом високої мінералізації розсолів } \\
\text { У відкладах міо-плейстоцену біля соляного діапіру виявлена циркуляція ви- } \\
\text { сокомінералізованих розсолів вилуговування, що сформувалися внаслідок } \\
\text { розчинення галогенних порід }[26,27]\end{array}$ \\
\hline & $\begin{array}{l}\text { Західна частина West } \\
\text { Насkberry Dome, } \\
\text { узбережжя затоки } \\
\text { Луізіана; юра }\end{array}$ & $\begin{array}{l}\text { Галогенні відклади є джерелом високої мінералізації розсолів, що призво- } \\
\text { дить до їх перенасичення і аутигенного мінералоутворення } \\
\text { Навколосольові води спричинили катагенетичні перетворення відкладів, } \\
\text { суміжних із соляним штоком. Потік високомінералізованих розсолів вилу- } \\
\text { говування, направлений на суміжні відклади слугував джерелом сульфатів } \\
\text { кальцію. Бурінням виявлено прошарок з аутигенним кальцит-піритовим } \\
\text { цементом в міоценових пісковиках, суміжних із штоком на глибинах 1,4- } \\
2,1 \text { км на площі 1,5×1,5 км [33] }\end{array}$ \\
\hline & $\begin{array}{l}\text { Окраїнні карбонати } \\
\text { басейну Кеннінг, Ав- } \\
\text { стралія; девон }\end{array}$ & $\begin{array}{l}\text { Галогенні відклади є джерелом високої мінералізації розсолів, що призво- } \\
\text { дить до їх перенасичення і аутигенного мінералоутворення } \\
\text { Розсоли з високим вмістом хлоридів металів утворилися внаслідок роз- } \\
\text { чинення галогенних відкладів силуру в центрі басейну. Розсоли рухаються } \\
\text { по розломах простягання до окраїн басейну, що призводить до осадження } \\
\text { доломіту }[46,48]\end{array}$ \\
\hline \multirow{3}{*}{$\begin{array}{l}\text { Осадові басейни } \\
\text { конвергентних } \\
\text { окраїн (collision } \\
\text { margin burial, } \\
\text { margin cratonic } \\
\text { basins, foreland } \\
\text { basins) }\end{array}$} & $\begin{array}{l}\text { Басейни Urania, } \\
\text { Atalante і } \\
\text { Discovery,Середземне } \\
\text { море; міоцен }\end{array}$ & $\begin{array}{l}\text { Галогенні відклади є джерелом високої мінералізації розсолів } \\
\text { Розсоли донних «озер» сформувалися внаслідок підводного розчинення } \\
\text { месинських евапоритів (що виходять на поверхню дна моря чи близько до } \\
\text { неї), наявність яких підтверджена сейсмічними даними [31] }\end{array}$ \\
\hline & $\begin{array}{l}\text { Передкарпатський } \\
\text { прогин; міоцен }\end{array}$ & $\begin{array}{l}\text { Внаслідок розчинення галогенних товщ формуються розсоли вилуговуван- } \\
\text { ня із високим вмістом брому, йоду, бору і літію, приурочені до палеозой- } \\
\text { ських та юрських відкладів (ділянки Мединичі, Коханівка та Уріж) [19] }\end{array}$ \\
\hline & $\begin{array}{l}\text { Піренеї, Південна } \\
\text { Франція та Північна } \\
\text { Іспанія; тріас }\end{array}$ & $\begin{array}{l}\text { Глибинні пластові розсоли, що сформувалися внаслідок вилуговування } \\
\text { тріасових галогенних товщ по тріщинах та поверхнях тектонічних порушень } \\
\text { надходили до кристалічного фундаменту Піренеїв під час герцинського } \\
\text { орогенезу }[24,32,45]\end{array}$ \\
\hline
\end{tabular}


Продовження таблиці

\begin{tabular}{|c|c|c|}
\hline \multirow{2}{*}{$\begin{array}{l}\text { Осадові басейни } \\
\text { конвергентних } \\
\text { окраїн (collision } \\
\text { margin burial, } \\
\text { margin cratonic } \\
\text { basins, foreland } \\
\text { basins) }\end{array}$} & $\begin{array}{l}\text { Фомація Слейв Поінт, } \\
\text { Канада; девон }\end{array}$ & $\begin{array}{l}\text { Галогенні відклади є джерелом седиментогенних розсолів } \\
\text { Пізньокембрійське стиснення, пов'язане із орогенезом, призвело до ви- } \\
\text { тіснення басейнових розсолів через карбонати південної частини Скеляс- } \\
\text { тих гір і сформувало формацію доломітів осадження Прескуіле }[35,36]\end{array}$ \\
\hline & $\begin{array}{l}\text { Розлом Тімор, } \\
\text { північний-захід Ав- } \\
\text { стралії; силур }\end{array}$ & $\begin{array}{l}\text { Галогенні відклади є джерелом седиментогенних розсолів } \\
\text { Джерелом розсолів мезозойських вуглеводневих пасток слугують палео- } \\
\text { зойські евапорити. До активізації потоку розсолів призвела короткочасна } \\
\text { інверсія в міо-плейстоцені і пов'язаний із нею розвиток розломів, ви- } \\
\text { кликаний колізією Австралійської плити та південно-східної Азії, внаслідок } \\
\text { чого гарячі високомінералізовані розсоли глибинних галогенних товщ } \\
\text { мігрували по розломах у верхні горизонти }[30,37]\end{array}$ \\
\hline \multirow{3}{*}{$\begin{array}{l}\text { Пост орогенного } \\
\text { занурення (post } \\
\text { orogenic burial) }\end{array}$} & $\begin{array}{l}\text { Басейн Ебро, Іспанія; } \\
\text { тріас }\end{array}$ & $\begin{array}{l}\text { Галогенні відклади є джерелом високої мінералізації розсолів } \\
\text { За даними палеогідрологічних реконструкцій встановлено, що джерелом } \\
\text { розсолів соляних озер басейну Ебро в міоцені слугували тріасові ева- } \\
\text { порити Iberian range західної окраїни басейну. Вилуговування тріасових } \\
\text { галогенних відкладів відбувалося внаслідок глибинної циркуляції метео- } \\
\text { рних вод по розломах ущільнення окраїни басейну [39] }\end{array}$ \\
\hline & $\begin{array}{l}\text { Пермський басейн } \\
\text { (Anadarko, Midland } \\
\text { та Palo Duro Basins), } \\
\text { Західний Техас і } \\
\text { Оклахома; Формація } \\
\text { Сан Андрес, перм }\end{array}$ & $\begin{array}{l}\text { Розчинення галогенних товщ в пост-орогенній континентальній обстанов- } \\
\text { ці слугує джерелом розсолів для нижчезалягаючих напірних водоносних } \\
\text { горизонтів. Розсоли Na-Cl складу, що залягають неглибоко від поверхні } \\
\text { в підсольових відкладах (пісковиках) вздовж окраїн басейнів Anadarko, } \\
\text { Midland та Palo Duro, перетворилися на високомінералізовані внаслідок } \\
\text { розчинення галіту глибоко циркулюючими метеорними водами. Ці басейни } \\
\text { складають частину Пермського басейну Західного Техасу і Оклахоми [23, } \\
\text { 43] }\end{array}$ \\
\hline & $\begin{array}{l}\text { Басейн Альберта, } \\
\text { Канада; девон }\end{array}$ & $\begin{array}{l}\text { Приповерхневі розсоли вилуговування, що сформувалися внаслідок } \\
\text { розчинення галогенних відкладів басейну змішуються із меншмінералізо- } \\
\text { ваними глибокоциркулюючими метеорними водами напірних водоносних } \\
\text { горизонтів. В розрізі басейну є два типи розсолів: "важких розсолів", які } \\
\text { є седиментогенними (залишковими) евапоритовими розсолами, та "легкі } \\
\text { розсоли", що, ймовірно, сформувалися внаслідок розбавлення важких } \\
\text { розсолів в результаті глибинної циркуляції метеорних вод. Поверхня роз- } \\
\text { ділу між даними розсолами обумовлена неоднорідністю проникності порід } \\
\text { водоносного горизонту, та коливанням п'єзометричних рівнів [34] }\end{array}$ \\
\hline \multirow{3}{*}{$\begin{array}{l}\text { Активізації плат- } \\
\text { форм, активних } \\
\text { окраїн, накла- } \\
\text { дених синекліз } \\
\text { (interior sag basins, } \\
\text { interior cratonic, } \\
\text { intracratonic) }\end{array}$} & $\begin{array}{l}\text { Дніпровсько- } \\
\text { Донецька западина; } \\
\text { перм }\end{array}$ & $\begin{array}{l}\text { Галогенні відклади є джерелом високої мінералізації та підвищених кон- } \\
\text { центрацій мікроелементів розсолів, що призводить до їх перенасичення і } \\
\text { аутигенного мінералоутворення } \\
\text { У водоносному горизонті, приуроченому до нижньопермських теригенних } \\
\text { підсоленосних відкладів, виявлено високомінралізовані розсоли хлор- } \\
\text { кальцієвого складу із високим ступенем метаморфізації і підвищеним } \\
\text { вмістом мікрокомпонентів. На хімічний склад розсолів суттєво впливають } \\
\text { галогенні відклади, що найбільш проявляєтья в південно-східній час- } \\
\text { тині западини (наприклад, Шебелинська структура - мінералізація вод } \\
\text { сягає З14 г/л). Також виявлені новоутворення доломіту, ангідриту, бариту } \\
\text { та галіту в породах теригенної червоноколірної формації нижньої пермі } \\
\text { південно-східної частини ддЗ (Кобзівська, Мар'янівська, Північноволвен- } \\
\text { ківська площі) [19-21] }\end{array}$ \\
\hline & $\begin{array}{l}\text { Алжірська Сахара; } \\
\text { тріас }\end{array}$ & $\begin{array}{l}\text { Галогенні відклади є джерелом флюїду та вторинного мінералоутворення } \\
\text { В результаті надходження ропи галогенних товщ до нижчезалягаючих } \\
\text { горизонтів формуються метаморфізовані хлоркальцієві розсоли. Доведено } \\
\text { взаємозв'язок ступеня метаморфізованості розсолів з характером ката- } \\
\text { генетичних перетворень вміщуючих порід і їхнью карбонатно-сульфатною } \\
\text { мінералізацією (мінеральні новоутворення: кальцит, доломіт, гіпс, ангідрит, } \\
\text { барит), що вплинуло на колекторські властивості піщано-алевролітових } \\
\text { відкладів тріасового комплексу [13] }\end{array}$ \\
\hline & $\begin{array}{l}\text { Переддобрудзський } \\
\text { крайовий прогин; юра }\end{array}$ & $\begin{array}{l}\text { В зоні утрудненого водообміну виявлено розсоли хлор-натрієвого складу, } \\
\text { що, ймовірно, є седиментогенними водами басейну осадконакопичення } \\
{[19,20]}\end{array}$ \\
\hline
\end{tabular}


частини ДДЗ (Кобзівська, Мар'янівська, Північноволвенківська площі).

В багатьох регіонах встановлено генетичний зв'язок між доломітизацією карбонатних відкладів і вищезалягаючими галогенними товщами. Доломіт виповнює каверни, пори і тріщини - складає агрегати ромбо- і субромбоедричних кристалів у порожнинах порід, часто не зачіпаючи матриці, представленої недоломітизованим глинистим матеріалом. Локалізація доломіту в постлітифікаційних порожнинах, досконалість і відносно крупний розмір кристалів не залишають сумніву у катагенетичному характері мінералу (рис. 2, а).

На зв'язок катагенетичної доломітизації з розсолами нерідко вказує тенденція збільшення ступеня доломітизації під- і міжсольових порід у міру наближення до перекриваючих соленосних формацій. Така тенденція виявлена в девонських відкладах Прип'ятського прогину, юрських басейну Мексіканської затоки, силурійських басейну Мічіган $[10,12]$. Процес доломітизації полягає в обміні магнію розчину на кальцій вапняку (метасоматичне заміщення кальциту доломітом за реакціями Гайдингера і Маріньяка) [13]. Наприклад, внаслідок розчинення солей силуру в центрі басейну Кеннінг, Австралія, формуються розсоли з високим вмістом хлоридів металів. Розсоли рухаються по розломах простягання до окраїн басейну, що призводить до виповнення пустот аутигенним доломітом [46].

Аутигенний кальцит-піритовий цемент виявлено в міоценових пісковиках [33], суміжних із соляним штоком (західна частина West Hackberry Dome, побережжя затоки Луізіана на глибинах 1,4-2,1 км на площі 1,5×1,5 км. Навколосольові води спричинили галокатагенетичні перетворення відкладів, суміжних із соляним штоком. Результати дослідження ізотопного складу Sr, C та S цементів вказують на те, що Сa та S отримані внаслідок розчинення ангідритового покриву соляного штоку, а карбонат - частково внаслідок термохімічного окиснення метану, а також сульфатредукції при температурі $70^{\circ} \mathrm{C}$.

Механізм формування іншого широко розповсюдженого галокатагенетичного мінералу ангідриту розглянемо на прикладі Південного пермського басейну Північного моря (площа Leman), де галокатагенетичний сульфатний (ангідритовий) цемент в значній кількості виявлено в пісковиках формації Ротлігенд [44].
Крупнозернистий ангідритовий цемент виповнює у великих кількостях розломи на глибині 3,5-4 км.

У під- і міжсоленосних відкладах існує два способи кристалізації катагенетичних сульфатних мінералів: пасивне виповнення пустотного простору (цементація) і метасоматичне заміщення карбонатної породи (рис. 2, в, Г). Сульфати, що утворюються більш поширеним першим способом, представлені ангідритом і гіпсом. Другий спосіб властивий, як правило, ангідриту.

У підсольовому тріасовому комплексі Алжірської Сахари розповсюджені високомінералізовані (300-400 г/л) хлоркальцієві розсоли, походження яких пов'язане із надходженням ропи з вищезалягаючих галогенних товщ. Процеси вторинної доломітизації кальцитового цементу і карбонатних порід відбувалися за реакцією Гайдингера 3 випадінням галокатагенетичних сульфатних мінералів, що призвело до погіршення початкових колекторських властивостей тріасових піщано-алевритових відкладів. У міру збільшення ступеня метаморфізації вод від району Рурд Нус до Гассі-Туіль, Хассі-Туарегу та до Незлі Північ (з півдня на північ) у породах-колекторах тріасу цемент, переважно глинисто-кременистий змінюється ангидритово-доломітовим [13].

Основною причиною кристалізації катагенетичного гіпсу в середовищі розсолів (вилуговування) є ефект складного впливу концентрації хлористого натрію, що змінюється при розчиненні галогенних порід, на розчинність сульфату кальцію. Поява останнього в розсолах вилуговування зумовлена тим, що в над- і навколосоляних зонах розчиняються як хлоридні, так і сульфатні шари. При цьому розчиненню ангідритових порід передує їх перетворення в гіпс, чому сприяє більша розчинність ангідриту, ніж гіпсу, при невисоких (до $42^{\circ} \mathrm{C}$ ) температуpax [10].

Важливим мінеральним продуктом галокагагенезу в між- і підсоленосних зонах є галіт (рис. 2, д, е). Він широко представлений у під- і міжсольових комплексах Прип'ятсько-ДніпровськоДонецького авлакогену, Іркутського амфітеатру, Мічіганської западини, ряду басейнів ПівнічноЗахідної Європи [10, 17, 47].

Кристали й агрегати галіту заліковують каверни, пори, тектонічні тріщини, стилолітові шви в карбонатних і карбонатно-глинистих породах, формують порові цементи, виповнюють тріщини спайності в уламкових зернах піско- 

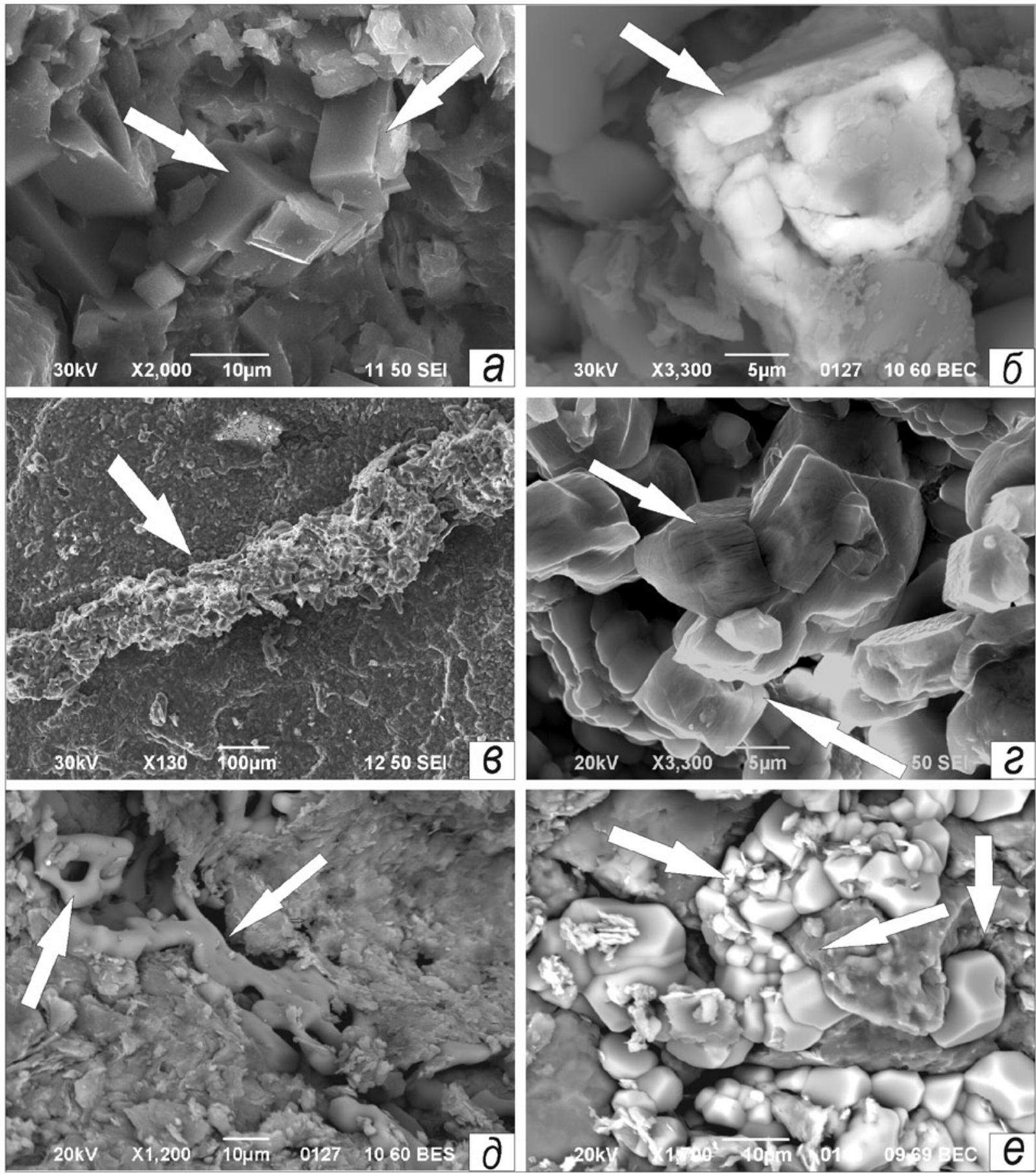

Рис. 2. Електронномікроскопічні знімки аутигенних галокатагенетичних мінералів, виявлених в нижньопермських підсольових червоноколірних теригенних відкладах південно-східної частини ДДЗ

а - кристали доломіту, св. Кобзівська-50, гл. 3219-3222 м; б - барит, св. Північноволвенківська-54, гл. 1433-1442, в - зерна ангідриту і галіту, що заповнюють тріщину в глинистій матриці, св. Кобзівська-50, гл. 3210-3219 м; г - збільшений фрагмент знімка в (кристали ангідриту); д - аутигенний галіт, св. Північноволвенківська-54, гл. 1485-1493; е - кристали аутигенного галіту, що заповнюють пустотний простір, св. Мар'янівська-50, гл. 3887-3899 м 
виків і гравелітів. У карбонатних відкладах розмір галітових новоутворень сягає 4-6 cм, у теригенних галітовий цемент сягає 20-30\% маси породи. Геологічною основою механізму формування катагенетичного галіту в під- і міжгалогенних комплексах слугує міграція маточних ропних розсолів, насичених або майже насичених по $\mathrm{NaCl}$. Це відбувається тільки в тих осадово-породних басейнах, де в галогенних товщах наявні хлоридні солі. Кристалізація галіту в порах, кавернах і тріщинах порід, що підстилають галогенні формації, можлива при змішуванні розсолів різного ступеня метаморфізації, що послідовно до них надходять.

Формування вторинного галіту в між- і підсольових відкладах може бути викликане флуктуаціями пластових температур, а також різким падінням пластового тиску при тектонічних рухах у зонах розломів [10, 26, 33].

\section{ПРАКТИЧНЕ ЗНАЧЕННЯ ГАЛОКАТАГЕНЕЗУ}

Розсоли галогенних формацій суттєво впливають на зміну колекторських властивостей порід нафтогазоносних басейнів [6-9]. Основними мінеральними продуктами галокатагенезу $\epsilon$ новоутворення доломіту, гіпсу, ангідриту, галіту та деяких інших мінералів (як, наприклад, у породах теригенної червоноколірної картамиської формації нижньої пермі південно-східної частини ДДЗ, під- і міжсоленосних відкладах девону Прип'ятської западини, підсольовому тріасовому комплексі Алжірської Сахари) [10, $13,21]$. Метасоматична доломітизація сприяє зменшенню пористості; мінералоутворення в пустотному просторі призводить до зниження ємнісних характеристик; ангідрит (рідше целестин, барит) виповнює каверни, пори і тектонічні тріщини; галіт - найбільш пізній із мінералів, що виповнюють пустотний простір, зазвичай заліковує порожнини, виповнені кристалами доломіту і ангідриту, включає більш ранні, рідше утворені одночасно з ним ангідритові пластинки. В інших випадках не виключено одночасне утворення цих мінералів чи більш пізнє формування доломіту. Співвідношення аутигенних мінералів віддзеркалюють багатоактний характер надходження сильномінералізованих розсолів різного хімічного складу в під- і міжсоленосні зони та складність процесів їх взаємодії з породами цих зон [9, 13, 42].

Взаємодія в системі вода-порода, зумовлена надходженням у підсольові комплекси розсолів, безпосередньо пов'язана із форму- ванням високомінералізованих металоносних вод (Fe, Mn, Pb, Zn, Cu, Ag, Li, Ba, Sr, Cs, Br, J, Sе та ін.) [2, 3, 6, 7, 12, 15, 17, 40, 46, 48]. Збагачення розсолів металами обумовлено їх надзвичайною агресивністю, що особливо проявляється при підвищених температурах і тисках зони утрудненого водообміну. В деяких випадках червоноколірні теригенні породи стають потужними колекторами металів і при катагенетичній взаємодії із розсолами здатні сильно збагачувати останні елементами-домішками. В присутності хлоридів лужних металів багато рудних компонентів виявляють здатність до комплексоутворення та утворюють добре розчинні сполуки типу $\mathrm{Na}_{3} \mathrm{MeCl}_{6}$ чи $\mathrm{NaMeCl}_{4}$. Тобто при галокатагенезі формуються металоносні рудні розсоли - має місце "розсольний рудогенез". Надалі у випадку активізації платформи такі рудоносні розсоли можуть по розломах надходити з нижнього структурного поверху у верхній і при наявності сірководню формувати жильні і стратиформні родовища кольорових і рідкісних металів, а також калійних солей і самородної сірки $[17,18,46,48]$.

Бром, відповідно до його розподілув галогенних породах (галіті, сильвіні, карналіті), здатен переходити в рідку фазу в значних кількостях за умови перекристалізації галогенних порід. У межах дДЗ йод-бромні розсоли приурочені до девонських, кам'яновугільних і нижньопермських відкладів (Північноголубівська, Шебелинська, Балаклейська, Північноволвенківська, Полтавська, Олексіївська та інші структури). В йод-бромних водах Передкарпатського прогину, що тяжіють до палеозойських та юрських відкладів, виявлено значні кількості бору і літію (ділянки Мединичі, Коханівка та Уріж) [19].

\section{ВИСНОВКИ}

Галокатагенез в осадових басейнах, що містять галогенні формації, є складним багатофакторним процесом, який протікає в багатокомпонентній системі вода (флюїд)-порода-газ(органічна речовина).

Вивчення процесів взаємодії в даній системі вода-порода поділяється на дослідження механізмів аутигенного мінералоутворення та зміни (метаморфізації) хімічного складу розсолів.

Показано, що потужні галогенні товщі у розрізі басейну седиментації суттво впливають на хімічний склад підземних вод (загальну мінералізацію, концентрації мікро- та макроелементів); можуть відігравати роль непроникного 
екрану, що спрямовує потік тепла і флюїдів на підсоленосні віклади; є джерелом флюїдів (седиметогенних розсолів, маточної ропи); слугують шляхами надходження глибинних флюїдів (зони бокових контактів солянокупольних структур); призводять до формування високомінералізованих розсолів і хімічного осадження з них аутигенних мінералів. Проведено узагальнення досліджень генезису розсолів, розглянуто гіпотези формування і метаморфізації їх хімічного складу та шляхів надходження в під- і міжгалогенні відклади.

Розсоли галогенних формацій суттєво впливають на зміну колекторських властивостей порід нафтогазоносних басейнів. Основними мінеральними продуктами галокатагенезу є доломіт, гіпс, ангідрит, галіт, барит та ін. Співвідношення аутигенних мінералів віддзеркалюють багатоактний характер надходження сильномінералізованих розсолів різного хімічного складу в під- і міжсоленосні зони та складність процесів їх взаємодії з породами цих зон.

Також із процесами взаємодії в системі вода-порода, зумовленої надходженням в підсольові комплекси розсолів безпосередньо повязано формування високомінералізованих металоносних вод (Fe, Mn, Pb, Zn, Cu, Ag, Li, Ba, $\mathrm{Sr}, \mathrm{Cs}, \mathrm{Br}$, J та ін.) — має місце "розсольний рудогенез".

Таким чином, вивчення процесів галокатагенезу має не тільки теоретичне (як окремого різновиду катагенетичних перетворень), але і практичне значення.

Дослідження цього типу катагенезує актуальним для України, де, як відомо, є чотири осадових басейни з потужними товщами галогенних формацій: Передкарпатський, Закарпатський, Переддобрудзький та Дніпровсько-Донецький.

1. Бабинец А.Е. Подземные воды юго-запада Русской платформы. - Киев: Изд-во АН УССР, 1961. - 377 с.

2. Валяшко М.Г., Поливанова А.И. Пути формирования рассолов и их перемещение в осадочной толще // Тр. Науч.-техн. совещ. по гидрогеологии и инж. геологии. - 1968. Вып. 2. - С. 177-188.

3. Варава К.Н., Вовк И.Ф., Негода Г.Н. Формирование подземных вод Днепровско-Донецкого бассейна. Киев: Наук. думка, 1977. - 160 с.

4. Дюнин В.И. Гидрогеодинамика глубоких горизонтов нефтегазоносных бассейнов. - М.: Науч. мир, 2000. $-472 \mathrm{c}$.

5. Коллекторские свойства пород на больших глубина / Под ред. Б.К. Прошлакова, В.Н. Холодова. - М.: Наука, 1985. - 256 с.

6. Колодий В.В. Подземные воды нефтегазоносных провинций и их роль в миграции и акумуляции нефти ( на примере Юга Советского Союза). - Киев: Наук. думка, 1983. - 248 с.

7. Кудельський А.В., Шиманович В.М., Махнач А.А. Структура подземных рассолов и процессы накопления химических элементов // Геология и геохимия соленосных формаций Украины. - Киев: Наук. Думка, 1977. - С. 112-121.

8. Лукин А.Е. Генетические типы вторичных преобразований и нефтегазонакопление в авлакогенных бассейнах / АН УССР. Ин-т геол. наук. - Препр. - Киев, 1989. - $52 \mathrm{c}$.

9. Махнач А.А. Галокатагенез - специфическая совокупность наложенных постдиагенетических процессов // Изв. АН СССР. Сер. геол. - 1981. - № 10. C. $141-145$.

10. Махнач А.А. Стадиальный анализ литогенеза: Учеб. пособие. - Минск: Изд-во БГУ, 2000. - 255 с.

11. Осадочные бассейны: методика изучения, строение и эволюция / Под ред. Ю.Г.Леонова, Ю.А. Воложа. - М.: Науч. мир, 2004. - 526 с.

12. Пиннекер Е.В. Основные гипотезы формирования состава концентрированных рассолов // Основы гидрогеологии. Гидрогеохимия. - Новосибирск: Наука, 1982. - С. 202-205.

13. Порошин В.Д. О катагенетических преобразованиях пород подсолевой толщи (триас Алжирской Сахары) // Литология и полез. ископаемые. - 1997. - №2. - C. 212-216.

14. Посохов Е.В. Химическая эволюция гидросферы. Л.: Гидрометиздат, 1981. - 286 с.

15. Сливко Е.С., Петриченко О.И. Акцессорный литий, рубидий и цезий в соленосных отложениях Украины. Киев: Наук. думка, 1967. - 154 с.

16. Смирнов С.И. Происхождение солености подземных вод седиментационных бассейнов. - М.: Недра, 1971. - $216 \mathrm{c}$.

17. Холодов В.Н. Новое в познании катагенеза. Сообщ. 1. Инфильтрационный и гравитационно-рассольный катагенез // Литология и полез. ископаемые. - 1982. - № 3. - С. 3-22.

18. Хрущев Д.П., Байбаков С.А., Галай С.А. и др. Рудообразование, связанное с некоторыми осадочными и наложенными процессами в соленосных бассейнах. - Киев, 1979. - 56 с.

19. Шестопалов В.М., Негода Г.М., Моісеєва Н.П. Формування мінеральних вод України. - К.: Наук. думка, 2009. - 312 c.

20. Шехунова С.Б. Геодинамічні аспекти типізації літогенезу соленосних формацій // Геол. журн. - 2009. № 4. - С. 99-106.

21. Шехунова С.Б., Шевченко О.А. Особливості катагенезу порід теригенної червоноколірної (картамиської) формації нижньої пермі (південно-східна частина Дніпровсько-Донецької западини) // Зб. наук. пр. Ін-ту геол. наук НАН України. - 2009. - Вип. 2. C. $170-184$.

22. Япаскурт О.В. Аспекты теории постседиментационного литогенеза // Литосфера. - 2005. - № 3, C. 3-30.

23. Bein A., Dutton A.R. Origin, distribution and movement of brine in the Permian Basin (USA) - A model for displacement of connate brine // Goelog. Society of Amer. Bulletin. - 1993. - Vol. 105. - P. 695-707.

24. Bitzer K., Travé A., Carmona J.M. et al. Floid flow in foreland basins during emplacement of thrust sheets: 
modelling the south-Pirenean Ainsa basin // Bull. Soc. Geol. France. - 1998. - Vol. 169. - P. 627-634.

25. Burrus J., Audebert F. Thermal and compaction processes in a young rifted basin containing evaporites; Gulf of Lions, France // American Assotiation Petroleum Geologists. - 1990. - Vol. 74. - P. 1420-1440.

26. Cassidy D.P., Ranganathan V. Groundwater Upwelling, Near Bay St. Elaine Salt Dome in the Southeastern Louisiana, as Inffered from Fluid Property Variations // Bull. American Assotiation of Petroleum Geologists. 1992. - Vol. 76. - P. 1560-1568.

27. Dworkin S.I., Land L.S. Petrographic and geochemical constraints on the formation and diagenesis of anhydrite cements, Smackover sandstones, Gulf of Mexico // J. Sedimemtary Research, Section A: Sedimemtary Petrology and Processes. - 1996. - Vol. 64. P. 339-348.

28. Gavrieli I., Yechieli Y., Halicz L. et al. The sulfur system in anoxic subsurface brines and its implication in brine evolutionary pathways: the Ca-Cl brines in the Dead Sea area // Earth and Planetary Science Letters. - 2001. Vol. 186. - P. 199-213.

29. Gvirtzman H., Stanislavsky E. Paleohydrology of hydrocarbon maturation, migration and accumulation in the Dead Sea Rift // Basin Research. - 2000. - Vol. 2. - P. 79-93.

30. LIsk M., Faiz M.M., Bekele E.B. et al. Transient fluid flow in the Timor Sea, Australia: implications for prediction of fault seal integrity // J. Geochemical Exploration. 2000. - Vol. 69. - P. 607-613.

31. Maria Bianca Cita. Exhumation of Messinian evaporites in the deep-sea and creation of deep anoxic brine-filled collapsed basins // Sedimentary Geology. - 2006. Vol. 188-189. - P. 357-378.

32. McCaig A.M., Tritlla J., Banks D. Fluid mixing and recycling during Pyrenean thrusting: Evidence from fluid inclusion halogen rations // Geochimica et cosmochimica acta. - 2000. - Vol. 64. - P. 3395-3412.

33. McManus K.M., Hanor J.S. Diagenetic evidence for massive evaporite dissolution, fluid flow, and mass transfer in the Louisiana Gulf Coast // Geology. — 1993. - Vol. 21. - P. 727-730.

34. Michael K., Michael H.J., Bachu S. New insights into the origin and migration of brines in Deep Devonian aquifers, Alberta, Canada // J. Geochemical Exploration. - 2003. - Vol. 80. - P. 193-219.

35. Morrow D.W., Zhao M., Stasiuk L.D. The gas-bearing Devonian Presqu'ile Dolomite of the Cordova embayment region of British Columbia, Canada: Dolomitization and the stratigraphic template // Bulletin American Association of Petroleum Geologists. - 2002. - Vol. 86. - P. 1609-1638.

36. Nesbitt B.E., Muehlenbachs K. Paleohydrology of the Canadian Rockies and origins of brines, $\mathrm{Pb}-\mathrm{Zn}$ deposits and dolomitization in the Western Canada Sedimentary Basin // Geology. - 1994. - Vol. 22. - P. 243-246.

37. O'Brien G.W., Lisk M., Duddy I.R. et al. Plate convergence, foreland development and falt reactivation: primary controls on brine migration, thermal histories and trap breach in the Timor Sea, Australia // Marine \& Petroleum Geology. - 1999. - Vol. 16. - P. 533-560.
38. Oliver J. Fluids expelled tectonically from orogenic belts; their role in hydrocarbon migration and other geologic phenomena // Geology. - 1986. - Vol. 14. P. 99-102.

39. Salvany J.M., Munos A., Perez A. Nonmarine evaporitic sedimentation and associated diagenetic processes of the south-western margin of the Ebro Basin (lower Miocene), Spain // J. Sedimemtary Research, Section A: Sedimemtary Petrology and Processes. - 1994. Vol. 64. - P. 190-203.

40. Spotl C., Longstaffe F.J., Ramseyer K. et al. Fluidrock reactions in an evaporitic mélange, Permian Haselgebirge, Austrian Alps // Sedimemtology. - 1998. - Vol. 45. - P. 1019-1044.

41. Stanislavsky E., Gvirtzman H. Basin-scale migration of continental-rift brines: Paleohydrogic modeling of the Dead Sea basin // Geology. - 1999. - Vol. 27. P. 791-794.

42. Stueber A.M., Saller A.H., Ishida H. Origin, migration and mixing the brines in the Permian Basin:geochemical evidence from the eastern Central Basin Platform, Texas // American Association of Petroleum Geologists Bulletin. - 1998. - Vol. 82. - P. 1652-1672.

43. Stueber A.M., Walter L.M. Origin and chemical evlution of formation waters from Sillurian-Devonian strata in the Illinois basin, USA // Geochimica et cosmochimica acta. - 1991. - Vol. 55. - P. 309-323.

44. Sullivan M.D., Haszeldine R.S. et al. Late anhydrite cements mark basin inversion; isotopic and formation water evidence, Rotliegend Sandstone, North Sea // Marine and Petroleum Geology. - 1994. - Vol. 11. P. 46-54.

45. Trave A., Calvet F., Sans M. et al. Fluid history related to the Alpine compression at the margin of the south-Pyrenean Foreland basin: the El Guix anticline // Tectonophysics. - 2000. - Vol. 321. - P. 73-102.

46. Wallace M.W. origin of dolomitization on the Barbwire terrace, Canning Basin, Western Ausrtralia // Sedimemtology. - 1990. - Vol. 37. - P. 105-122.

47. Warren J.K. Evaporites, brines and base metals: brines, flow and "the evporite that was" // Australian Journal of Earth Sciences. - 1997. - Vol. 44. - P. 149-183.

48. Warren J.K., Kempton R.H. Evaporite Sedimrntology and the Origin of Evaporite-Associated Mississippi Valleytype Sulfides in the Cadjebut Mine Area, Lennard Shelf, Canning Basin, Western Australia., in I.P. Montanez, J.M. Gregg, and K.L. Selton. Eds. Basinwide diagenetic patterns: Integrated petrologic, geochemical and hydrologic considerations // Tulsa OK. SEMP Spesial Publication. - 1997. - Vol. 57. - P. 183-205.

Інституту геологічних наук НАН України, Київ E-mail: stadnik_sm@ukr.net

Рецензент - канд. геол.-мінерал. наук С.Б. Шехунова 